\title{
KIRJANDUS KUI VASTUPANU Nõukogude Eestis Teise MAAILMASÕJA JÄRGSEL PERIOODIL
}

\author{
Tiit Hennoste
}

Eesti kultuuri ja eriti kirjandust nõukogude perioodil on tõlgendatud kui püsivat üldrahvaliku vastupanu vahendit, milles "salakoodid" ühendasid kultuuritegijaid ja rahvast. Selle pildi loojaks on olnud rahvuslik-vastupanuline lugemisviis, milles kirjandusteose lugemisel on määrav teose suhe nõukogude võimuga. ${ }^{1}$ Taustaks oli olukord, kus vaba poliitiline avalikkus ei olnud võimalik ja kultuur, eriti kirjandus, sai üheks poliitika aseaineks. See omakorda soodustas ka kultuuritegelaste rolli muutumist, kellelt oodati tegutsemist "eesti rahva häälena", "avaliku südametunnistusena" jms. Kirjandust nähakse selles lugemisviisis võitlusväljana võõra võimu ja kohaliku vaimu vahel, kusjuures keskne selles võitluses on rahvuslik küsimus. Käesolev töö on üks katse seda pilti mitmekesisemaks rääkida ja tuua esile vastupanu erinevaid variante.

Vastupanuvõitluse terminoloogia on mitmekesine. ${ }^{2}$ Suhteid kirjanduse ja totalitaarse võimu vahel võib vaadata skaalana, mille ühes otsas on kollaboratsionism, mille kandja teotseb otseselt võimu huvides, ja teises otsas avalik-teadlik vastupanu. Nende vahele jääb mugandumise ala. ${ }^{3}$ Käesolevas kirjutises on kasutatud keskse mõistena vastupanu. Artikkel tegeleb ainult kirjanduse tegijate kavatsusliku vastupanuga avalikus sfääris, mis võib avalduda nii eksplitsiitselt kui ka varjatult (vihjete, metafooride jms kaudu). Kõrvale jäävad vastupanu erasfääris (nt kodused vestlused) ning lugeja tõlgenduslik vastupanu, kes vastupanumärke teosesse sisse loeb (just

\footnotetext{
1 Ma ei käsitle siin üldpilti pikemalt, vt Johanna Ross, Aira Kaalust Mari Saadini: nõukogude eesti naisarenguromaan ja selle lugemisviisid, Dissertationes litterarum et contemplationis comparativae Universitatis Tartuensis (Tartu Ülikooli Kirjastus, 2018), 21-41.

2 Eri vastupanumõistete kohta vt Eve Annuk, “Totalitarismi ja/või kolonialismi pained: miks ja kuidas uurida nõukogude aega”, Võim \& kultuur, toim Arvo Krikmann, Sirje Olesk (Tartu: Eesti Kirjandusmuuseum, 2003), 18-26, 29-30.

3 Vastupanu totalitaarses ühiskonnas on alati vastupanu ja mugandumise sulandumine. Põhimõtteliselt oli kirjanduse avaldamine nõukogude ametlikes väljaannetes alati ühtlasi ka koostöö võimuga. Vajalik oli teadlik või ebateadlik enesetsensuur ning allumine toimetajate ja tsensorite keeldudele-käskudele.
} 
see oli oma aja oluline lugemisstrateegia, kusjuures mälestused näitavad, et neid märke loeti sisse igale poole, kuhu vähegi võimalik).

Vastupanu mõiste lähtub arusaamast, et on olemas võimu surve. Ma lähtun seisukohast, et vastupanust saab kõnelda seni, kuni on saavutatud olukord, mil vastupanu nõudvad tingimused või tegevused on kadunud või vastupanijate jaoks piisavalt nõrgenenud. Sealt edasi saame kõnelda positsioonide hoidmisest või vastupanu lõppemisest.

Surve loomuse ja eesmärkide järgi jagan vastupanu neljaks. Esiteks, totalitaarse süsteemi eesmärgiks on allutada nii üksikisik kui kogu ühiskond tugevatele piirangutele. Sellest lähtudes on üheks püüdluseks vabadus, nii üldise hüve ja ideena kui ka isikliku vabadusena. Teiseks, kuna totalitaarne süsteem toetub ühele kindlale ideoloogiale, siis saab eesmärgiks olla vastupanu valitsevale ideoloogiale kas ideoloogiavaba kirjanduse või mingi muu ideoloogia nimel. Kolmandaks, eesti kirjanduse puhul on alati tõstetud eraldi esile rahvuslikud eesmärgid, millel on vähemalt kaks tahku. Üks on rahvuse ühendamine, rahvusühtsuse hoidmine; teine oma identiteedi, kultuuri ja keele säilitamine. Esimene eeldab võimu, mille eesmärk on rahvusühtsuse hävitamine; teine aga võimu, mille eesmärk on rahvuse, selle kultuuri või keele hävitamine. Neljandaks, totalitaarne süsteem võib kehtestada ka omapoolsed kirjanduse tegemise käsud või normid. Sel juhul on oluline esteetiline vastupanu ametlikule kirjanduse tegemise viisile.

\section{Varasemast uurimisest}

Nõukogude võimu ja kirjanduse suhted on olnud kirjandusuurijate arutluse aineks pikka aega. Ülevaatlikult on teemat käsitletud nõukogude aja järgsetes kirjanduslugudes, samuti laiemalt kultuurist kõnelevate ülevaadetes. ${ }^{4}$ Ilmunud on dokumendikogumikud tsensuuri tegevusest. ${ }^{5}$ Mitmed ennekõike sajandivahetuse ümber ilmunud artiklikogumikud puudutavad

\footnotetext{
${ }_{4}$ Epp Annus et al., Eesti kirjanduslugu (Tallinn: Koolibri, 2001); Cornelius Hasselblatt, Eesti kirjanduse ajalugu (Tallinn-Tartu: Tartu Ülikooli Kirjastus, 2016); Toomas Karjahärm, Väino Sirk, Kohanemine ja vastupanu: Eesti haritlaskond 1940-1987 (Tallinn: Argo, 2007).

5 Kalju-Olev Veskimägi, Nõukogude unelaadne elu: tsensuur Eesti NSV-s ja tema peremehed (Tallinn, 1996); Endel Priidel, Vägikaikavedu ehk Vaim ja võim 1940-1990 (Tallinn: Eesti Keele Sihtasutus, 2010); Punatsensuur mälestustes, tegelikkuses, reeglites, koost Enno Tammer (Tallinn: Tammerraamat, 2014).
} 
ka siinset teemat. ${ }^{6}$ Lisaks on ilmunud mitmeid eraldi uurimusi ja artikleid. Palju on teemat käsitletud kirjanike ja literaatide mälestustes (nt Lembe Hiedel, Aksel Tamm, Sirje Kiin, Teet Kallas, Peet Lepik jt). ${ }^{8}$

Käesolevas ma ei anna ülevaadet konkreetsetest uurimustest, vaid viitan neile vastavate teemade juures. Ülevaatlikult paistab silma kolm asja. Esiteks, autorite vaatepunkt ei ole niivõrd vastupanu-, kui võimukeskne, vaadeldakse seda, mida võim (partei, tsensuur jne) tegi kirjanduse allutamiseks. Teiseks, enim kirjutatakse Stalini ajast ja stalinistlikust kultuuripoliitikast. Ja kolmandaks, keskne on nõukogude võimu ja rahvusliku kirjanduse võitluse teema.

Järgnevalt vaatan vastupanu eri variante konkreetsemalt, jagades selle kolme traditsioonilisse ajalooperioodi: aastad 1946-56 ehk Stalini aeg, aastad 1956-68/70 ehk "sula" ja 1970. aastate algusest perestroikani.

\section{Stalini aja vastupanu}

Stalini aega iseloomustab teravalt totalitaarne ühiskond, milles vabadus oli viidud miinimumi ja ühiskonnaelu allutatud rangelt marksistlik-leninlik-stalinlikule ideoloogiale. See toetus arusaamale omavahel võitlevatest klassidest, milles rahvusühtsust käsitleti kodanliku propagandana. Samas

\footnotetext{
6 Muutuste mehhanismid eesti kirjanduses ja kirjandusteaduses: ettekandeid ja artikleid 1999, koost Marin Laak ja Sirje Olesk (Tartu: Eesti Kirjandusmuuseum, 200o); Kohandumise märgid, koost ja toim Virve Sarapik, Maie Kalda ja Rein Veidemann (Underi ja Tuglase Kirjanduskeskus, 2002); Võim \& kultuur: uurimusi 1940. aastate eesti kirjandusest, koost Anneli Kõvamees ja Piret Viires (Tallinn: Eesti Keele Sihtasutus, 2011).

7 Mart Velsker, "Stalinismi võidud ja kaotused kuuekümnendatel aastatel”, Vikerkaar, 10-11 (1998), 119-127; Olaf Kuuli, Sula ja hallad Eesti NSV-s: kultuuripoliitikast aastail 1953-1969 (Tallinn: Olaf Kuuli, 2002); Anu Raudsepp, "Kirjandus ja stalinistlik kultuuripoliitika Eestis", Muutuste mehhanismid eesti kirjanduses ja kirjandusteaduses, 116-127; Sirje Olesk, "Neljakümnendad I: murrang kodumaal", ibid., 149-172; Sirje Olesk, “"Laine põhi”: kirjandusest ja selle kontekstist Eestis aastatel 1950-1953”, Võim \& kultuur, 465-480; Sirje Olesk, Anu Saluäär, Palat nr. 6 (Loomingu Raamatukogu, 2017); Eve Annuk, "Totalitarismi ja/või kolonialismi pained: miks ja kuidas uurida nõukogude aega", Võim \& kultuur, 13-39; Eve Annuk, "Stalinismi “Teised": Ilmi Kolla kui teisitimõtleja”, Methis, 20 (2017), 77-98; Ross, Aira Kaalust Mari Saadini.

8 Lembe Hiedel, “"Loomingu” Raamatukogu alaeast: märkmeid ja meenutusi aastaist 1957-1973", Vikerkaar, 5/6 (1995), 138-149; 7 (1995), 80-85; 8 (1995), 67-75; Aksel Tamm, Aga see oli üks mees (Tallinn: Kuldsulg, 2003); Aksel Tamm, Ütle tsensor, milleks sulle käärid? (Tallinn: Kuldsulg, 2012); Teet Kallas, Mälestused I-II (Tallinn: Faatum, 2011, 2014); Peet Lepik, "Mälestusi "kuuekümnendate põlvkonna" stardiepisoodidest", $A k a$ deemia, 2 (2015), 195-238; Sirje Kiin, Pühendused: mälestusi eesti kirjanikest (Tallinn: Hea Lugu, 2018). Vt ka vastupanu kohta ajakirjanduses Epp Lauk, Tiiu Kreegipuu, "Was it all pure propaganda? Journalistic practices of 'silent resistance' in Soviet Estonian journalism”, Acta Historica Tallinnensia, 15 (2010), 167-19o.
} 
ei saa me kõnelda tol perioodil eesti rahvuse või keele hävitamisest kui eesmärgist. Rahvusliiduvabariikides oli eesmärgiks sisult sotsialistlik ja vormilt rahvuslik kultuur, mille tarvis võim kehtestas kirjanduses kindlad põhimõtted sotsialistliku realismi normide näol.

Stalini aja algused 1940. aasta suvest 1941. aasta suveni ja 1944. aasta oktoobrist 1946. aasta suveni moodustavad kirjanduse ajaloos vaheperioodi, mida ma siin ei käsitle. ${ }^{9}$ Stalini aja võim juhtis kultuuri partei otsustega, mis olid määratud rangeks täitmiseks. Esimene neist oli "Ajakirjadest "Zvezda" ja "Leningrad"” (14.08.1946), järgnesid "Draamateatrite repertuaarist ja selle parandamise abinõudest" (26.08.1946), "Kinofilmist "Suur elu"” (04.09.1946), "V. Muradeli ooperist "Suur sõprus"” (10.02.1948). Neile lisandusid juhtide kõned, kinnised juhised/kirjad ja partei kesklehe Pravda juhtkirjad.

Siinse teema seisukohast on olulisim 1946. aasta suvel ilmunud ÜK(b)P Keskkomitee otsus ajakirjade Zvezda ja Leningrad kohta ja seda saatev Andrei Ždanovi kõne. ${ }^{10}$ Need märkisid maha piirid ja esitasid nõuded, mida järgides tuli kirjanikel edaspidi tegutseda. ${ }^{11}$

Kirjanduse ja kriitika põhimeetodiks kuulutati sotsialistliku realismi nõukogulik doktriin, mis kirjanike liidu tollases põhikirjas kõlab järgmiselt: "Sotsialistlik realism, olles nõukogude ilukirjanduse ja kirjandusliku arvustuse põhimeetodiks, nõuab kunstnikult võltsimatut ajaloolis-konkreetset tõelisuse kujutamist selle revolutsioonilises arengus. Seejuures kunstilise kujutamise tõepärasus ja ajalooline konkreetsus peab ühtuma ülesandega kujundada ja kasvatada töötavat rahvast ideeliselt ümber sotsialismi vaimus." ${ }^{2}$ Sellega seostub leninlik arusaam parteilisest kirjandusest, põhialuseks V. I. Lenini artikkel "Partei organisatsioon ja parteiline kirjandus” (1905). Ždanovi järgi oli väär arusaam, nagu oleks sõja järel tulnud aeg luua ajaviitekirjandust ja kirjutada lihtsalt hästi. Vastupidi,

\footnotetext{
9 Minu ülevaateid vt Tiit Hennoste, "Hüpped modernismi poole II: 20. sajandi eesti kirjandusteadus Euroopa kirjandusteaduse taustal, 14. loeng: piiriaeg, Vikerkaar, 12 (2008), 70-83; "Ametiühingust rühmituseks. Eesti Nõukogude Kirjanike Liit kui kirjandusrühmitus ja tema esimene põhikiri kui kirjanduslik manifest", Uurimusi 1940. aastate eesti kirjandusest, 13-44.

10 "Ajakirjadest "Zvezda" ja "Leningrad”. ÜK(b)P KK otsusest 14. augustil 1946. a.", Looming, 9 (1946), 963-966; "Seltsimees Ždanovi kõne ajakirjade "Zvezda" ja "Leningrad” kohta”, Looming, 10/11 (1946), 1103-1124.

${ }_{11}$ Vt ülevaatlikult Annus et al., Eesti kirjanduslugu, 345-352 (osa autor Sirje Olesk). Detailne ülevaade: Pekka Lilja, "Ždanovlusest sulailmadeni: märkmeid nõukogude eesti kirjanduspoliitikast”, Keel ja Kirjandus, 3-5 (1990), 156-166, 229-238, 286-294. Siinkirjutaja pilti vt Hennoste, "Hüpped modernismi poole II".

12 Kirjandusmuuseum (edaspidi KM), Eesti kultuurilooline arhiiv (edaspidi EKLA), F8 M14: 1. Trükitud: Uurimusi 1940. aastate eesti kirjandusest, 39-44.
} 
just rahuliku arenemise tingimustes suurenevat kirjanduse ideoloogilised ülesanded. Sisuliselt keelati neutraalne, apoliitiline, mitteideoloogiline kirjandus, aga kaudsemalt ka meelelahutuskirjandus. Kirjanike liidu liikmetele pandi juba liidu põhikirjas kindlad ülesanded: koostöö partei ja nõukogude võimuga, aktiivne osalemine oma loominguga sotsialismi ülesehitamisel, töölisklassi huvide kaitsmine, Nõukogude Liidu tugevdamine jms. Selline kirjandus pidi olema vaba kodanlik-anarhistlik-üliinimeselikust individualismist.

Otsuse teine punkt puudutas nõukogude kirjanduse põhivaenlast, milleks kuulutati estetism (kunst kunsti pärast), formalism (vormikultus) ja idealistlik filosoofia. Nende keskse kandjana nähti 20. sajandi alguse vene dekadentsi, sümbolismi ja imažinismi.

Kolmas meile oluline punkt lähtub Lenini kahe kultuuri teooriast artiklis "Kriitilisi märkmeid rahvusküsimuse kohta" (1913). Lenini järgi on igas rahvuslikus kultuuris kaks klassikultuuri: majanduslikult valitseva klassi (=kodanluse) kultuur ning demokraatliku ja sotsialistliku kultuuri elemendid. Sellest tuleneb küsimus suhtumisest minevikukultuuri. Lenini järgi ei heida marksism kodanliku ajastu väärtuslikke saavutusi kõrvale, samas tuleb rahvuslikust kultuurist tema järgi võtta ainult selle demokraatlikud ja sotsialistlikud elemendid, sealjuures aga ainult vastukaaluks kodanlikule kultuurile ja kodanlikule natsionalismile. ${ }^{13}$

Ždanovlikke arusaamu hakati Eestis ellu rakendama kohe otsuse järel. Septembris 1946 esitas partei keskkomitee esimene sekretär Nikolai Karotamm kolmteist eesti nõukogude kirjanduse peapuudust, mille seas olid mh apoliitilisus, ideelagedus, dekadents ja estetism. ${ }^{14}$ Oktoobris aga kõneles ta sellest, et eesti kirjanduse vaimne pärand tuleb läbi töötada ja kõik reaktsiooniline ja tagurlik selles kõrvale heita. ${ }^{15}$ Pärandi ümberhindamisele andis hoogu kinnine kiri 1947. aasta juulist teadlastest abielupaari Niina Kljujeva ja Grigori Roskini kohta, mille tuumaks oli võitlus lääne ees "lömitamise" vastu teaduses, aga ka laiemalt kogu kultuuris. ${ }^{16}$

13 Lisaks on taustaks oluline ka "Lev Tolstoi kui vene revolutsiooni peegel" (1908). Need tööd on eesti keeles ilmunud mitmeid kordi, vt nt V. I. Lenin, Kirjandusest ja kunstist (Tallinn, 1964), 91-95, 131-141, 250-254.

14 Nikolai Karotamm, "Märkmeid kirjanduslikest päevaküsimustest", Looming, 9 (1946), 975-988.

15 Sirp ja Vasar, 19.10.1946.

16 Vt pikemalt Tõnu Tannberg, “"Kiri ütleb, et peab tuginema vene teadusele...”: ÜK(b)P Keskkomitee 16. juuli 1947. aasta kinnine kiri professorite N. Kljujeva ja G. Roskini süüasjas ja selle ajaloolisest kontekstist”, Methis, 20 (2017), 168-178. Seal on trükitud ka kirja tõlge. 
Eesmärgiks seati esialgu kirjanike ideoloogiline ja kirjanduslik kasvatamine ja ümberkasvatamine, mis kestis väikeste kõikumistega kuni 1949. -50 . aastani. ${ }^{17}$ Siis tuli kasutusele terav mustvalge vastandus ning kirjanike harimine asendus liidust (ja sellega ka kirjandusest) väljaviskamisega, osal juhtudel ka autorite vangistusega. ${ }^{18}$ Kirjanike karistamine moodustas sealjuures vaid osa laiemast kultuuri allutamise operatsioonist, mille taga olid nii stalinistliku ideoloogia postulaadid kui ka võimuvõitlus tollases partei- ja kultuuriladvikus.

Stalini aja kirjandusliku vastupanu keskne ja praktiliselt ainus vorm oli vaikimine. Selle üks, sealjuures harv variant oli põhimõtteline sahtlisse kirjutamine, mida esindas näiteks Uku Masing, kelle jaoks Stalini aeg oli viljakas periood, millega on dateeritud luulet tema seitsmes kogus. ${ }^{19}$ Samuti oli viljakas algaja kirjanik Raimond Kaugver, kes kirjutas enne 1953. aastat novellikogu ja romaanid, mis Oskar Kruusi sõnul polnud mõeldudki avaldamiseks, kuna nii selget nõukogude korra kriitikat poleks keegi trükki lubanud. ${ }^{20}$ Samas, Betti Alver kirjutas sel perioodil vaid mõne üksiku luuletuse. $^{21}$

Teine variant oli valikuline vaikimine. Põhirühma moodustavad siin kirjanikud (ennekõike luuletajad), kes alustasid nõukoguliku kirjanduse katsetega, kuid hakkasid pärast teravat ideoloogilist kriitikat sahtlisse kirjutama. Näiteks sobib tuua Minni Nurme, kelle teine kogu "Pikalt teelt" (1947) sai aluseks 1948. aastal toimunud esimesele kirjanike liidu uudisteoste hindamiskoosolekule. ${ }^{22}$ Selle kriitikast leiame kõik olulised ždanovlikud kriteeriumid puuduste märkimiseks: nõrgalt on toodud esile üldrahvalik võitlus, keskne on isiklik õnn, domineerivad kannatused, mida autor käsitleb positiivse nähtusena, puudub nõukogulik ellusuhtumine, autor pole vabanenud idealistliku maailmavaate iganditest idealiseerides

17 Ülevaatlikult kirjanikele esitatud nõudmistest, kirjanike tööplaanidest, suhtumisest õppimisse jms: Anu Raudsepp, "Kirjandus ja stalinistlik kultuuripoliitika Eestis", Muutuste mehhanismid eesti kirjanduses ja kirjandusteaduses, 116-127.

18 Järgnes võitlus kosmopolitismi vastu. 1948. aasta jaanuaris tõi Ždanov oma kõnes käibele mõiste "kodumaatu kosmopoliit" (bezrodnȳı kosmopolit), 1949. aasta 28. jaanuaris ilmus Pravda artikkel "Ühest antipatriootlikust teatrikriitikute rühmast". Eestis sai kosmopoliidi tiitli nt luuletaja Ain Kaalep (vt "Kosmopoliit taskuväljaandes", Noorte Hääl, 30.07.1949).

19 Uku Masing, Piiridele pyydes, Aerutades hurtsikumeistriga, Hurtsik lammutaks enda, Kirsipuu varjus, Itkud isale, Unenägija tessaraktis, Surija sandiristilt.

20 Oskar Kruus, "Raimond Kaugveri rada kirjandusse", Keel ja Kirjandus, 9 (2000), 641-642.

21 Karl Muru, Betti Alver (Tartu: Ilmamaa 2003), 108, 126.

22 "Minni Nurme luuletuskogu "Pikalt teelt" arutelu NE Kirjanike Liidus", Sirp ja Vasar, 07.02.1948. 
loodusnähtusi jne. Nurme avaldas tänu puuduste väljatoomise eest ja vaikis luuletajana kümme aastat, tegeldes tõlkimisega ja kirjutades sahtlisse. ${ }^{23}$

Valikulise vaikimise teiseks võimaluseks oli keskendumine võimu poolt soositud teemade ja vaateviiside asemel sellistele, mis ei olnud otseselt keelatud, kuid samas ei näidanud ka otsest toetust võimule. Sellena on nt Cornelius Hasselblatt tõlgendanud Aadu Hindi “Tuulise ranna” esimese osa esimest varianti (1951), mis keskendus tegelaste majanduslikele ja sotsiaalsetele suhetele, jättes kõrvale poliitika. ${ }^{24}$ See vaikimine jäi tol perioodil pigem teoreetiliseks võimaluseks. Hindilt nõuti poliitilise liini lisamist, mida ta ka kiiresti tegi (teose teine variant aastal 1952).

Kolmandat tüüpi valikut iseloomustab kahestumine. Selle näidisautoriks sobib varalahkunud Ilmi Kolla, kes sai tuntuks luuletusega "Nukrad hetked" (kirjutatud 1953), milles on koos klassikalise romantilise kitšiliku armastusluule olulised elemendid: armastus, kurbus, kaduvuse ja surma aimus. Kolla kirjutas sahtlisse luulet iseendale ning selle kõrval avaldamiseks mõeldud tarbeluulet, milles püüdis igati arvestada võimuvaateid esindavate kirjanike, kriitikute ja toimetajate seisukohti. ${ }^{25}$ Tarbeluule avaldamise üheks mõjuriks oli Kolla puhul kindlasti soov luulega elatist teenida. Samas, kirjanike liidu liikmete puhul ei piisa sellest põhjendusest, neil oli otsene kohustus ennast avaldada.

Siin kerkib põhimõtteline küsimus, kuidas sellist kahestumist tõlgendada. Eve Annuk on toonud ühes artiklis välja kolm tõlgendust. Ühes kohas nimetab ta Kolla tegevust otseselt vastuhakuks stalinlikule ideoloogiale. ${ }^{26}$ Teisal kutsub ta seda ebateadlikuks vastuhakuks ja kolmandas kohas ütleb, et Kolla ei suutnud kirjutada nõuetele vastavalt oma loomelaadi eripära tõttu. Minu seisukoht toetab ennekõike viimast arusaama ja kindlasti ei tõlgenda ma seda tegevust ideoloogilise vastupanuna stalinismile. Tegemist on nähtusega, mida on hiljem uurimustes mitmete nn lüürilise andelaadiga autorite puhul esile toodud: nende andelaad ei sobinud kokku ždanovliku pateetilise sotsrealismi doktriiniga.

Minu tõlgenduse järgi on siin tegemist ennekõike vastupanuga isikliku andelaadi järgimise ja selliselt looja sisemise vabaduse nimel. Seda

\footnotetext{
23 Minni Nurme tütar Eeva Park kirjutab oma raamatus Minu kuninglikud kaelkirjakud (Tallinn: Hea Lugu, 2018), et ema muutus sõja ajal Venemaal tegelikult nõukogudevastaseks.

24 Cornelius Hasselblatt, "Stalinismi pikk vari üle tuulise ranna: Aadu Hindi “Tuulise ranna" kohandamine/kohandumine meie päevadeni”, Cornelius Hasselblatt, Eemalt vaadates (Tartu: Tartu Ülikooli Kirjastus, 2005), 292-305.

25 Vt nt Annuk, "Stalinismi “Teised”: Ilmi Kolla kui teisitimõtleja”, 77-98.

26 Annuk, "Stalinismi “Teised”: Ilmi Kolla kui teisitimõtleja”, 83, 86.
} 
vastupanu tõlgendan ma esteetilise autentsuse metafoori kaudu. Autentsuse idee lähtub sellest, et inimeses on sisemine mina, mille ümber on maskid, õpitud, kultuuri või ühiskonna poolt peale pandud omadused ja nõuded. Autentsuse määr on ise-olemise määr, see kui palju astub inimene vastu välise võimu, ideoloogiate, väärtuste jms pealetungile. Esteetiline autentsus on oma sisemise esteetilise mina järgimine.

\section{6. aastast 1970. aastate alguseni}

Olukord kirjanduses hakkas teisenema 1950. aastate keskel koos isikukultuse kriitikaga ja järgneva vabama ajajärguga. ${ }^{27}$ Ühiskonnas on tegu kahe olulise muutusega. Esiteks algas aeg, mille jooksul võim ise suurendas oluliselt senist vabaduse määra ühiskonnas, kuigi korduvate tagasilöökidega. Marksistlik-leninlik ideoloogia kui ühiskonnaelu alus püsis, aga sellest kadus osaliselt stalinistlik komponent ja ühiskonnas (sh kirjanduses) võimaldati tekkida ideloogiavabadel aladel.

Kirjandust ja kunsti tõlgendas võim endiselt ideoloogilise võitluse areenina ja kirjanikke-kunstnikke ideoloogiarinde võitlejatena, kelle keskne ülesanne oli tõsta esile sotsialismi ja nõukogude rahva suuri saavutusi. Samas vähenes sel perioodil tugevalt kultuuri juhtimine partei otsustega. Nüüd andis partei üldisi hinnanguid ja suuniseid oma kongressidel ning juhtide kõnedes. Sealjuures võttis nt Hruštšov pidevalt sõna kirjanduse ja kunsti kohta, järgnevad juhid aga pigem hoidusid sellest. ${ }^{28}$ Suur osa juhtimisest suunati nüüd kirjanike eneste kätte, mis tõstis oluliseks kirjanike kongresside ja koosolekute otsused, kirjanike liidu juhtide sõnavõtud, parteilastest kirjanike rolli. ${ }^{29}$ Samuti lõdvenes sotsialistliku realismi normide kogum, kuigi sellest kui nõukogude kirjanduse põhimeetodist formaalselt kunagi ei loobutud. Ka sel perioodil ei saa kõnelda võimupoolsest eesti rahvuse või keele hävitamisest.

Teiseks, kui 1950. aastatel uskusid paljud nõukogude võimu kiiret kadu, siis sama kümnendi lõpuks oli selge, et see jääb püsima. Uus olukord nõudis inimestelt, sh kirjanikelt enese positsioneerimist sellesse ühiskonda.

\footnotetext{
27 Seda perioodi on nimetatud sulaks, kuigi rangemalt tõlgendades seostub sulaga vaid N. Hruštšovi võimuaeg, mis lõppes aastal 1964.

28 Vt nt N. Hruštsov, "Kirjandus ja kunst olgu tihedasti seotud rahva eluga", Looming, 9 (1957), 1286-1301.

29 Vt nt Sirje Olesk, "Kuuekümnendad aastad ENSV Kirjanike Liidus: muutuste aeg", Looming, 8 (2014), 1154-1174; Sirje Olesk, "Kolm kongressi: ENSV Kirjanike Liidu ajaloost aastatel 1954-1966", Keel ja Kirjandus, 3 (2015), 153-162.
} 
Muuhulgas tõstatas see olulise küsimuse, kuidas asetada ennast pikemaajaliselt vastupanu-mugandumise-koostöö teljel.

Muutunud parteilised juhtimisviisid tõstsid tol perioodil valitsevaks kirjanike omavahelise võitluse. Järgnevate aastate kirjandusareenil moodustasid ühe poole taganevad stalinistliku liini jätkajad (Endel Sõgel, Eduard Päll, Ants Saar, Max Laosson, Gustav Naan jt) ning nendega koos tegutsenud funktsionärid ja tsensuur. Teist poolt määratleda ei ole võimalik, tegemist oli paljude pisileeridega, kusjuures samad kirjanikud võisid eri küsimuses kuuluda eri leeridesse. Osa neist olid sealjuures poolmuutujad, kes astusid vastu stalinismile, aga distantseerisid ennast radikaalsematest uuendustest. Lisaks kuulus sellesse poolde ka osa liberaalsemaid võimuesindajaid. Kahe vahele jäid mitmed autorid, kes mõnes küsimuses olid stalinismi positsioonil ja teises tegutsesid liberaalidena (nt Lembit Remmelgas, Juhan Smuul, Johannes Semper, Endel Nirk). ${ }^{30}$

Sel perioodil toimusid mitmed omavahel põimuvad võitlused, mis haarasid kõiki vastupanu aspekte. Üldistavalt ühendas neid küsimus suhtumisest "kodanlikku" kultuuri, mille alla mahuvad nii suhtumine avangardismi-modernismi, mittemarksistlikusse filosoofiasse kui ka kultuuripärandisse ja laiemalt Eesti vabariigi aegsesse kirjandusse. Sealjuures oli keskne avalik vastupanu. ${ }^{31}$

\section{Mitteparteilise kirjanduse eest}

Sotsialistlikus realismis tähendas sula algus normide lõdvenemist ja osa ždanovlike arusaamade hukkamõistmist. ${ }^{32}$ Üks esimesi vastupanusid (kui mitte esimene) oli vastupanu totaalse parteilisuse nõudele, mis tõi kirjandusse ideoloogivabad alad (mh ka ajaviitekirjanduse). ${ }^{33}$ Selles osas

\footnotetext{
30 Ülevaatlikult vt nt Kuuli, Sula ja hallad Eesti NSV-s. Häid detaile eri autorite positsioonidest pakub Aksel Tamm, Aga see oli üks mees.

31 Käesolevasse artiklisse ei mahu oluline taustsüsteem, muutused nõukogude vene kirjanduses, mis mõjutasid pidevalt otseselt või kaudselt ka eesti olukorda. Vt ülevaatlikult Istoriya russkő̆ literaturȳ XX veka, ch. 2, red. V. V. Agenossov (Moskva: Yurait, 2014).

32 Vt nt "Mõnedest nõukogude kirjanduse arenemise küsimustest: sekretariaadi aruanne NSVL Kirjanike Liidu juhatuse III pleenumil”, Sirp ja Vasar, 24.05.1957.

33 Eestis peegeldas ajaviitekirjanduse positsiooni muutumist ennekõike tõlkeraamatute sari "Seiklusjutte maalt ja merelt" (alates 1955. a lópust, A. Dumas, W. Scott, J. F. Cooper jt). Lääne mõistes ajaviitekirjandus kujunes meil välja alles 199o. aastatel, seetõttu ei saanud see muutuda ka vastupanu vahendiks (vrd osa ulmekirjandusest Venemaal). Eestis algas peatselt olmekirjanduse tootmine, mille tippaeg jääb aastaisse $1975-85$. Sealjuures jäi olmekirjandus läbi nõukogude aja negatiivseks mõisteks, seda nii parteile kui ka kõrge kirjanduse apologeetidele. Meie teema seisukohast on need pigem kirjanduse muganemise näited.
} 
algas muutumine juba 1950. aastate keskel ja jätkus ka 1960. aastate esimesel poolel.

Kõige selgemad muutused toimusid luules, kuhu ilmus taas lüüriline, romantiline temaatika, motiivideks loodus, armastus, mõtisklused, kurbus jms. Siin algasid muutused kohe Stalini surma järel ja samas suunas liikusid nii vahepealsed sahtlisse kirjutajad kui ka senised stalinistid (Juhan Smuul, Debora Vaarandi, Paul Rummo jt). Osalt oli tegu võimupoolse liberaliseerimisega, mis tähendas teatud ideoloogiavabade teemade ja lüürilise andelaadi aktsepteerimist, osalt aga vastupanuga vanadele stalinistidele, kellele ei meeldinud endiselt kasvõi looduse ihalus, mille eest sai süüdistusi biologismis jms.

Oluline võitlus käis nüüd nn kodanikulüürika ümber. Selle võitluse kõrghetk oli hilisemate uurijate ja osalejate poolt sümboliks tõstetud vabavärsipoleemika, mille lähtepunktiks sai Hermelini (kirjandusteadlase Endel Nirgi) paroodia "Porikuu sonaat-fantaasia opus 13" Jaan Krossi, Ellen Niidu ja Ain Kaalepi luulest. ${ }^{34}$ Järgnes väitlus ajakirjanduses, asjasse sekkusid filoloogiaüliõpilased Peet Lepiku eestvedamisel, kes kirjutasid pöördumise "Avalik kiri Hermelinile" ajalehele Noorte Hääl jne.

Vabavärss oli antud juhul ennekõike sümbol. ${ }^{35}$ Kritiseeritud luule näol oli tegu kodanikuluulega, mis vanameelsete jaoks oli arusaamatu, vastupidiselt talle partei poolt seatud eesmärkidele. Nad nägid uuendajate luuleviisis taganemist realismist ja kommunistlikest ideedest, dekadentlike nähtuste tagasitoomist, "lillekesi" kangelasliku kaasaja asemel, autorite "mina upitamist" jms. ${ }^{36}$

Seda võitlust on hiljem tõlgendatud erinevalt. Sirje Olesk näeb siin murrangut, mille käigus eesti luule kaotas oma "vahepeal omandatud "nõukoguliku" näo". ${ }^{37}$ Mart Velsker on tõlgendanud seda võitlusena nõukoguliku ja isegi stalinliku paradigma sees. ${ }^{38}$ Ta toob tõestusena esile uuendajate töödes olevad nõukogulikud reaalid (töö poetiseerimine, uute maailmade loomise paatos, "demiurgide" kummardamine, Ameerika Ühendriikide satiiristamine jms) ning seob selle stalinismi paatosega. Minu seisukoht

34 Sirp ja Vasar, 12.11.196o. Vt ülevaatlikult: Sirje Olesk, "Luule tõus kodumaal”, Annus et al,. Eesti kirjanduslugu, 431-432 ja eriti Peet Lepik, "Mälestusi "kuuekümnendate põlvkonna" stardiepisoodidest", Akadeemia, 2 (2015), 195-238 (seal on ära trükitud ka asjaomased luuletused).

35 Vabavärss ise taastoodi eesti luulesse juba 1956. aastast alates (Ralf Parve ja Vladmir Beekman) ning Ain Kaalep avaldas tollal mh mitmeid teoreetilisi käsitlusi vabavärsist (nt Ain Kaalep, “Teoreetilisi märkmeid vabavärsist”, Keel ja Kirjandus, 5 (1959), 257-273).

36 Vt Lembit Remmelgas, "Mis on uus ja mis on vana", Sirp ja Vasar, 24.02.1961.

37 Raamatus Annus et al., Eesti kirjanduslugu, 432.

38 Velsker, "Stalinismi võidud ja kaotused kuuekümnendatel aastatel”, 123. 
jääb siin kahe vahele. Ma tõlgendan seda muutusena nõukogude süsteemi, kuid mitte stalinismi sees. Selles luules avalduv maailma avardumise paatos jm jooned on minu arvates seotud ajastuomase optimismiga (kosmose vallutamine, tehnikauuendused jms), teisalt aga tolle aja laiema mõtteviisiga, milles kõneldi tagasiminekust "halva" Stalini juurest "hea" Lenini juurde ja nõukogude süsteemi Stalini-eelsesse aega. Sellega koos tõsteti kõrgemale ka Stalini-eelne vene nõukogude kirjandus, mis oli tulvil optimistlikke utoopiaid ning vormilt paljuski avangardistlik-modernistlik, samuti lääne modernistlik kirjandus, mis oli ennast tugevalt sidunud kommunismiga (B. Brecht jt). ${ }^{39}$

Proosas algas samal ajal aeglane ja tagasilöökidega võitlus seni keelatud teemade ringi laiendamiseks (Raimond Kaugver, Veera Saar, Paul Kuusberg, Lilli Promet jt), kus oluliseks tähiseks sai Rudolf Sirge "Maa ja rahva" ilmumine $1956 .{ }^{40}$ Paralleelselt hakkasid tekstidesse ilmuma tegelased, kelle käitumine ei olnud määratud klassikuuluvusega (nn ankeediga): laisad kehvikud, karjeristidest kommunistid jmt. ${ }^{41} \mathrm{Ka}$ siin ei saa rääkida ametliku kirjandusdoktriini kiirest muutumisest. Johanna Ross on toonud ära Lilli Prometile saadetud äraütlemiskirja tema romaani "Meesteta küla" kohta (12. detsembrist 1960), milles öeldakse, et kirjastus ei saa olla nõus Suure Isamaasõja tagalaelu kujutamisega, kuna teoses "puudub töölisklassi ja kolhoositalurahva massiline kangelaslikkus, piiritu patriotism, ennastsalgav töö võidu heaks". ${ }^{42} J a$ veel kümnendi keskel põhjustas suure poleemika Enn Vetemaa lühiromaan "Monument” (1965) parteilasest karjeristiga minajutustaja rollis.

Olulise haruna ilmus platsile satiir, mille partei oli tõstnud loosungina üles juba Stalini aja lõpus. "Puudusi tuleb ravida. Meil on vaja Gogoleid ja Štšedrine”, kirjutas Pravda 1952. aasta 7. aprillil. ${ }^{43}$ Eesmärgiks kuulutati

\footnotetext{
39 See teema jääb käesoleva artikli piiridest välja. Oluline on siiski osutada vene kultuuris nn kuuekümnendike põlvkonnale (Jevgeni Jevtušenko, Andrei Voznessenski, Juri Trifonov jpt), kelle jaoks oli tagasiminek Lenini juurde oluline idee, nagu ka revolutsioonilisus ja koos sellega nt Majakovski, Meierholdi, Brechti, Hemingway, aga ka Fidel Castro ja Che Guevara austamine. Selle vene põlvkonna mõju eesti tolle aja kirjandusele on mu arvates suurem ja laiem kui eesti uurijad on seni soovinud näha.

40 Neid avardumisi on kirjeldatud kõigis kirjanduslugudes, vt Annus et al., Eesti kirjanduslugu, 412-419; Hasselblatt, Eesti kirjanduse ajalugu, 505-530.

${ }^{41}$ Johanna Ross toob mitmeid näiteid naiskirjandusest (nt Luise Vaheri "Emajõe jutustus" (1960), "Rindeõde" (1966) jms), vt Ross, Aira Kaalust Mari Saadini.

42 Ross, Aira Kaalust Mari Saadini, 139.

43 "Lechit' nado nedostatki. Nam Gogoli i Shchedrinȳ nuzhnȳ" ("Preodolet' otstavanie dramaturgii”, Pravda, 07.04.1952). See juhtkiri polnud muidugi Pravda eriarusaam. Teema oli tõstnud Stalin 26. veebruaril (K. Simonovi järgi) ja sama juttu kordas XIX parteikongressil Georgi Malenkov. Pravda artikkel oli oluline muutuse väljendaja. Selles
} 
paljastada nõukogude ühiskonnas veel esinevaid “üksikuid väärnähtusi” (nt bürokraatia ja väikekodanlik mõtteviis), lääne imperialismi, sõjaõhutamist jms. Juhan Peegli järgi pidi satiiri põhitunnus olema autori "jäägitult hukkamõistev suhtumine negatiivsesse nähtusesse”, ning väljanaermine toimuma "positiivse idee nimel, vankumatu usuga positiivse võidusse, negatiivse kaotusesse". ${ }^{44} 1957$ asutati ajakiri Pikker, mis hakkas pakkuma sotsiaalset satiiri enam-vähem lubatud piirides, pilgates bürokraate, majavalitsust, rumalaid ülemusi jms. ${ }^{45}$

Mitut suundumust kokku võtvaks märgiliseks algustööks on minu jaoks Juhan Smuuli följetonistlik "Muhulaste imelikud juhtumised..." $(1955 / 57) \cdot{ }^{46}$ Siin tõstis Smuul positiivse kangelasena esile tavalised tõsised tööinimesed, kolhoosnikud ja meremehed, negatiivses rollis aga nii lõngused kui ka stalinismi jäikadest põhimõtetest kinnihoidjad. Smuul toetus Muhu kohalikule rahvalikule pärimusele, aga viitas ka vabariigi aja kommertskultuurile. Konkreetselt astus ta vastu lähenemisele, milles inimese klassikuuluvus määras tema kirjanduslikud käitumismallid. Lisaks irvitas ta "hea ja parima" võitluse üle kirjanduses ning parodeeris Majakovski ideid labastavat didaktilist luulet (nt luuletus "Direktiiv nr 1", mis räägib sellest, kuidas käituda raudteejaamades).

Kokkuvõttes ei tähendanud muutus loomulikult võimalust kirjutada kõigest. Ühest küljest sai kirjutada sellest, mis oli lubatud, kuigi mitte võimu poolt eelistatud. Tulemuseks oli vaikimise ja sahtlikirjanduse kadumine. Teisest küljest kujunes välja kirjanike sisetsensuur, mille tõttu jäeti töö mõnikord lihtsalt kirjutamata, proovimata liikuda lubatu ja lubamatu piiril või piire laiendada. Aksel Tamm tsiteerib näiteks Aadu Hindi ütlemist, et "Tuulise ranna" viies osa jääb kirjutamata, sest ta ei saa kirjutada nii, nagu asjad olid. ${ }^{47}$

kritiseeriti mh nähtusi, mis said nimeks "konfliktituse teooria", "konflikt hea ja parima vahel", "tegelikkuse lakeerimine". Eesti kirjanduses andis vajalikud hinnangud Lembit Remmelgas, "Kinni pidada elutõest!", Looming, 7 (1952), 821-833.

44 Juhan Peegel, "Följetonist", Abiks kirjasaatjale (Tartu: "Edasi”, 1958), 63-81.

45 Pikker oli ilmunud ka Rahva Hääle lisana 1943-46.

46 Juhan Smuul, Muhulaste imelikud juhtumised Tallinna juubelilaulupeol (Tallinn: Eesti Riiklik Kirjastus, 1957), esmatrükk ajalehes Sirp ja Vasar, 29.07-30.12.1955 (vaheaegadega 10 numbris).

47 Tamm, Aga see oli üks mees, 65. 


\section{Modernismi-avangardismi ja mittemarksistliku ideoloogia eest}

Teine esteetilise vastupanu teema on võitlus modernismi-avangardismi ja sellega tihedalt seotud mittemarksistlike mõtteviiside eest.

Avangardistlikud tekstid ilmusid juba 1950. aastate lõpus Tartu boheemlaste luulesse, kuid jäid tol ajal sahtliluuleks. Keskne oli siin Artur Alliksaare loomingus 1960. aasta paiku toimunud murrang, aga samal ajal kirjutasid avangardismi ka mitmed algajad Alliksaare-mõjulised luuletajad (nt Paul-Eerik Rummo ja Andres Ehin). Avalikult hakkas modernne luule, nii sümbolism ja dekadents kui ka 20. sajandi "progressiivne" modernism ja avangard, tulema esmalt tõlgetena (Baudelaire, Verlaine, Verhaeren, Apollinaire, Éluard, Prévert, Garcia Lorca jt). Kümnendi alguses ilmus see kitsale ringile mõeldud väljaannetes, nagu ülikooli õppevahendid, milles ilmunud tõlgete olulist mõju endale on märkinud nt Paul-Eerik Rummo. ${ }^{48}$ Suur hoog saabus aastatel 1965-67, kui ilmusid järjest mitmed olulised luulekogumikud: Prévert (1965), Garcia Lorca (1966), soome modernistide kogumik (1967), Baudelaire (1967). Nende paralleeliks filosoofilisel tasandil võib pidada prantsuse kommunistist filosoofi Roger Garaudy "piirideta realismi" kontseptsiooni (1963), mille põhjalik tutvustus ja kirjandust puudutav essee Kafkast ilmusid ka eesti keeles. ${ }^{49}$

Ka eesti kirjandus hakkas muutuma kümnendi keskel, olulisteks pöördemärkideks said P.-E. Rummo "Lumevalgus... lumepimedus" (1966) ja Jaan Kaplinski “Tolmust ja värvidest” (1967). Need manifesteerisid luuletamisviisi, milles ühendati modernsusevaimuline kujundikeel rahvusliku või üldinimliku ideestikuga. Seda luulet hakati nimetama assotsiatiivseks luuleks, mis on pigem modernsust varjav eufemism (rahvusvaheline kirjandusteadus seda praktiliselt ei kasuta). Assotsiatiivsus on olnud kogu modernse luule oluline aluspõhi sümbolismist-dekadentsist alates. Sellisena oli uus luule ka esteetilise vastupanu luule, sidudes ennast vaenulikuks kuulutatud kirjandusvooludega.

Sellele järgnes aastatel 1968-69 juba otsene pöördehetk avangardi, mida märgivad neli olulist teost: Artur Alliksaare luulevalimik "Olematus võiks ju ka olemata olla" (1968), Arvo Valtoni novellikogu "Kaheksa jaapanlannat"

$48 \mathrm{Nt}$ Tartu Riikliku Ülikooli õppevahendite sarjas ilmunud XIX-XX sajandi väliskirjanikke, 3. vihik: valik luulet (Tallinn: Tartu Riiklik Ülikool, 1962). Vt Paul-Eerik Rummo, "Märkmeid luuletõlkimisest", Tõlkija hääl III, Eesti Kirjanike Liidu tõlkijate sektsiooni aastaraamat (Tallinn: SA Kultuurileht, 2015), 41.

49 Vt Jaak Kangilaski, "Vaidlustest marksistlikus esteetikas”, Looming, 11 (1965), 17071718; Roger Garaudy, "Kafka”, Franz Kafka, Protsess, Loomingu Raamatukogu 40-43 (1966), 179-232. 
(1968), Mati Undi jutustus/lühiromaan "Mõrv hotellis" (1969) ja Paul-Eerik Rummo näidend "Tuhkatriinumäng" (1969). Neile järgnesid Andres Ehini sürrealistlik "Uks lagendikul" (1971), nelja mehe "Närvitrükk" (1971), Raul Meele kirjutusmasinaluule, Vaino Vahingu freudistlik-afektiivsed jutud, Rein Saluri novellid jm. Tegu oli täieliku lahkulöömisega igasugusest realismist. ${ }^{50}$ Sellega oli vastupanu sotsialistlikule realismile eesti kirjanduses jõudnud sisuliselt lõpule. Esteetiline vabadus oli kätte võidetud.

\section{Filosoofilise vabaduse ja autentsuse eest}

Modernismi ja avangardismiga seostub tugevalt vastupanu mittemarksistlike mõtteviiside ja autentsuse nimel. ${ }^{51}$ Mittemarksistlik mõtteviis tähendas tollases eesti kirjanduses põhiliselt kolme suunda: ida filosoofiad (budism, zen-budism, taoism jm), eksistentsialism ja klassikaline psühhoanalüüs (Freud, Jung), mis tõusid oluliseks ennekõike 1960. aastate teisel poolel. ${ }^{52}$ Nendest mõjudest on kõnelnud enda puhul nt Paul-Eerik Rummo, Jaan Kaplinski, Mati Unt, Arvo Valton, Vaino Vahing jt. Mõjude konkreetsem taust on antud juhul kirju. Siia kuuluvad Uku Masing, kirjanike konkreetsed huvid ja lugemus (nt psühhoanalüüs Vahingul või loodusrahvaste kultuurid Kaplinskil), 1960. aastate keskel läänemaailma haaranud vaimustus zen-budismist, biitlite mõjul tõusnud India-huvid, soome avangardkirjandus jm.

Ainus teema, mis siin suure avaliku konflikti põhjustas, oli eksistentsialism. Sotsrealismi-modernismi võitluse lõpupiiri ongi nähtud eksistentsialismi (täpsemalt võõrandumise) diskussioonis aastail 1968-69, mille algatas vana stalinist Eduard Päll. ${ }^{53}$ See lõpetati ülevalt tulnud käsu korras, kuid samas on seda vaadatud kui viimast diskussiooni, milles "kroonukriitikat" üldse tõsiselt võeti. Eksistentsialismi olulisi mõisteid kasutati

\footnotetext{
50 Ma olen seda murret kirjeldanud hüppena modernismi poole, vt Tiit Hennoste, "Hüpped modernismi poole: eesti 20. sajandi kirjandusest Euroopa modernismi taustal. Kodueesti modernism I", Vikerkaar, 11 (1995), 87-94; "Ibid., Kodueesti modernism II", Vikerkaar, 3 (1996), 69-76; "Ibid., Kodueesti modernism III", Vikerkaar, 4 (1996), 86-93. 51 Ma olen seda perioodi ja teemat varem käsitlenud nt: Tiit Hennoste, "Eksistentsialism ja heroism. Mõttevahetus: Eesti eksistentsiaalsusest”, Looming, 8 (2011), 1139-1148. 52 Tõlgetena avaldati olulisi eksistentsialismitekste 1960. aastatel (Camus' "Katk" 1963 ja “Võõras” 1966, Sartre’i “Sõnad” 1965), ida filosoofiatekste 1970. aastate lõpus ja 1980. aastatel ("Dhammapada" 1977, "Bhagavadgita" $1980 \mathrm{jm}$ ), freudismi baastekstid jäid avaldamata.

53 Eduard Päll, "Eksistentsialismist, absurdismist ja meie kirjanduskriitika mõttepinge tsentrumist", Sirp ja Vasar, 03.12, 13.12.1968.
} 
kirjanduse analüüsimisel 1960. aastate lõpus endiselt (nt Jaak Rähesoo Undist ja Rummost). ${ }^{54}$

Filosoofilise vabadusega seostub tugevalt võitlus autentsuse nimel. Siin põimusid ideaalidena mäng ja juhus, poliitiline vabadus ja üldine sõltumatus ning vastasena nõukogude süsteem (ja igasugune süsteem), mis ahistab inimese vabadust ja sõltumatust: institutsioonid ja riik, masinad ja ratsionaalsus, konformism ja väikekodanlik raamistatud eluviis. See vastupanuliin algas vaikselt 1960. aastate algupoolel ja saavutas samuti tipu kümnendi teisel poolel ja lõpus, haakudes tugevalt tollase Euroopa ja Ameerika Ühendriikide noorte mõttemaailmaga, mille taustal põimusid Ameerika kontra- ja popkultuuri maailm, biitnikute ja hipide ideed ja ideaalid.

Vastupanu alguspunktiks võib panna Artur Alliksaare ja tema jüngrite tegevuse 1960. aastate algupoole Tartus, mis tõstis esile vabaduse, juhuse, mängu ja vastuolud. Andres Ehin on seda kirjeldanud nii: "Werneris korraldas ta [Alliksaar] poliitlugemisi, lugedes kohvikukülalistele ette näiteks poliitökonoomia või teadusliku kommunismi õpikut. Ma ei mäleta, et ta oleks omalt poolt midagi lisanud. Siin-seal ta küll köhatas mõnes äärmiselt ebasobivas kohas. Aga ta esinemisviis oli nii veider, et kohvijoojate näod tõmbusid tahes-tahtmata naerule. Kui mõni parteilane Alliksaart vaikima püüdis sundida, häbistas luuletaja teda kui rahvavaenlast, kes tema ideoloogilist ettevõtmist saboteerib." ${ }^{55}$ Sama kümnendi algupoolel avaldas teistsugust vabaduse luulet Arvi Siig. Tema lõnguseluules tegutsevad noored tõstetud kraega mantlites, mängib džäss, põlevad kaupluste neoonreklaamid (Ameerika elu sümbolid) ning igatsetakse biitniklikku minekut teele ("Reporter värsikaameraga" 1966). Kümnendi lõpus tegutsesid juba Arvo Valtoni absurdsete motiveerimata tegude inimesed (nagu "Rohelise seljakotiga mees”, kelle tegevus meenutab väga Alliksaare tegemisi kümnendi algul). Valton irvitab ratsionaalse ja deterministliku mõtteviisi üle. Ta kirjeldab ühiskonnamehhanismi, mis on rooste läinud ja näitab, kuidas tavaliste inimeste motiveerimata teod lõhuvad selle masinavärgi rutiinselt toimiva skeemi. Samasse kuulub Mati Unt oma tundlike tegelastega, kelle olulisimaks ideeks on sisemise autentsuse ja siiruse otsingud ning sotsiaalse mimikri ja teeskluse vihkamine. Siia kuuluvad ka kümnendilõpu biitnike- ja hipidemõjulised almanahhipõlvkonna autorid, kes tõid uue vastupanuviisi - katse jääda omakirjastuslike almanahhidega väljapoole

\footnotetext{
54 Vt nt Aare Pilv, "Olemasolu-Eesti”, Looming 6, (2011), 843-855. Ühtlasi hakkas sel ajal kujunema arusaam eesti "oma” eksistentsialismist. Vt sellekohast diskussiooni ajakirjas Looming, nr 6-12 (2011).

55 https://www.vooremaa.ee/mentor-artur-boheemlaste-kuningas/ (autor Riina Mägi, vaadatud 12.12.2018).
} 
ametlikku kirjastussüsteemi. See jäi siiski lühiajaliseks hüppeks aastatel 1968-73, hiljem ilmus vaid üksikuid selliseid väljaandeid. ${ }^{56}$

Almanahhiautorina alustas nt terav nõukogudevastane ja ühtlasi ennast biitnikuna identifitseerinud Johnny B. Isotamm, kes kuulutas oma õigust vabadusele, omaenda saatusele ja valikutele. Tema vihkamise objektid on keskmised, standardiseeritud inimesed, tehisajudega nõukogude kodanikud, konformistid jmt. Sealjuures oli Johnny B. ainus tollane oluline autor, kes lõpetas teadlikult kirjutamise ja avaldamise aastal 1974, sest ei tahtnud muutuda süsteemi osaks, mis võtab tema sõltumatuse. ${ }^{57}$

Kogu selle suuna võttis kokku autentsuse kui suurima väärtuse otsimine, nüüd juba sügavamal ja ka kirjandusvälisel tasandil võrreldes kümnendi alguse võitlusega esteetilise autentsuse eest. Autentsus ei ole siin üksnes eetilise looja, vaid ka eetilise inimese imperatiiv. Samas võimaldas autentsus pöörata individuaalsel tasandil positiivseks ka fatalismi, kuna ta lähtus arusaamast, et iseenda äratundmine ei ole fatalistlik alistumine, vaid eneseleidmine.

\section{Estetismi ja metakeele eest}

Ždanovi doktriini järgi olid sotsialistliku realismi kesksed vaenlased estetism, formalism, dekadents jmt. Siin toimus kaks olulist vastupanuvõitlust. Esimene oli võitlus nende mõistetega seotud autorite ja rühmituste koha eest kirjandusajaloos (Noor-Eesti, F. Tuglas, G. Suits jt). Üldiselt tasandil oli see ühtlasi võitlus selle nimel, mida võtta kaasa "kodanlikust" kultuurist, sügavamal aga võitlus eesti kirjanduse pidevuse eest ja stalinistliku kultuurilise katkestuse vastu. Teine oli küsimus kirjandusest kõnelemise viisidest ja terminoloogiast ehk võitlus metakeele eest. ${ }^{58}$

56 Vt almanahhide kohta: Kersti Unt, Marja Unt, Seilates sadamata (Tallinn: Varrak, 2012), 15-83.

57 Vt siinkirjutaja arusaamu pikemalt Tiit Hennoste, "Möiratus tänavalt. Johnny B-d üle lugedes", Looming 6, (2015), 853-860.

58 Omaette teema on pagulaskirjandus, mis jääb siin käsitlemata. 1950. aastate lõpus hakkas muutuma ametlik arusaam pagulastega suhtlemisest. 1958 asutati ajaleht Kodumaa ja 1960 loodi väliseestlastega sidemete arendamise ühing VEKSA, mis oli sisuliselt julgeoleku käepikendus. Said alguse tihedamad kontaktid kodu- ja väliseestlaste vahel, mis tõid kaasa mh mitmeid konflikte Rootsi ja Kanada pagulaste seas. Kirjanduses hakati 1950. aastate lõpus kirjutama Suitsust ja Underist ja ilmusid üksiknäited pagulaskirjandusest. Trükiplahvatus toimus ka siin aastatel 1965-67, mil ilmusid nt August Mälgu "Kevadine maa" (1965), Karl Ristikivi "Imede saar" (1966) jt. Ajalehe Kodumaa lisa "Faktid ja kommentaarid" avaldas Kalju Lepiku "Sina oled kuusik" (1965), Arno Vihalemma "Ühe Pärnust pärit poeedi palgejooni" (1965) ja Bernard Kangro "Võõramaa õhtu" (1966). Selle järel käis Keele ja Kirjanduse Instituudis 1967-68 arutelu selle 
Juba stalinismist peale oli oluline teema suhtumine Eesti vabariigi aegsesse kultuuri. Selle lähtepunktiks oli arusaam, mille järgi "kodanliku" aja rahvuslik kultuur, sh kirjandus oli täielikult või vähemalt põhiliselt mandunud nähtus. Keskseks jäi ka uuel perioodil võitlus uusromantismi, sümbolismi ja impressionismi ning nendega seotud kirjanike koha üle kirjandusloos. Selle võitluse oluline kese jääb 1950. aastate teise poolde, mil vastamisi seisid kaks lähenemist. Stalinistlikku vaateviisi esindas arusaam, et Stalini ajal esines üksikuid hoolimatu suhtumise ilminguid kultuuripärandisse, teist poolt väljendas fraas "rahvuslik nihilism", mida kasutas Stalini-aja suhtumise iseloomustamiseks esimesena Lembit Remmalgas. ${ }^{59}$

Olukorra muutumist illusteerivad hästi mahud, mis on antud kirjandusloos "dekadentidele" ja stalinistlikus kirjandusdoktriinis neile vastanduvale proletaarsele kirjandusele. 1953. aastal valminud Endel Sõgla toimetatud "Eesti kirjanduse ajaloo"60 neljandas osas käsitles "dekadentlikku" suunda eesti kirjanduses üks peenes kirjas lehekülg ilma ainsagi nimeta. Realismist rääkivast 160 leheküljest oli proletaarsele kirjandusele pühendatud 40. Selle raamatu uuendatud trükis $(1956)^{61}$ oli "dekadentidest” üle viie lehekülje, mh lühikilde Tuglasest, Suitsust, Ridalast, Underist. 190 realismiküljest oli proletaarsele kirjandusele pühendatud veidi üle 2o. See oli ka piir, millest stalinistlikud uurijad ei soovinud kaugemale minna. Keele ja Kirjanduse Instituudi tollane direktor Eduard Päll teatas instituudi aastaaruandes, et sellega on vulgaarsotsioloogilised moonutused eesti kirjandusteaduses põhiliselt likvideeritud. ${ }^{62}$ Siiski olid muutused 1960. aastatel suured. Samuti Sõgla peatoimetamisel ilmunud suure "Eesti kirjanduse ajaloo" (EKA) kolmas köide (1969, käsitleb perioodi 19. sajandi lõpukümnenditest 1917. aastani) räägib selgest murrangust. Seal on kunagistest "dekadentidest" juttu ligikaudu 130 leheküljel 640-st ning proletaarne kirjandus mahub 37 leheküljele. Lisaks tuldi seal sisuliselt tagasi sõjaeelse terminikasutuse juurde, võttes põhimõistetena taas kasutusele uusromantismi, impressionismi ja sümbolismi. ${ }^{63}$

üle, kuidas kajastada pagulaskirjanikke koostatava "Eesti kirjanduse ajaloo" viiendas köites (Eva Ahven, Pilk paberpeeglisse (Tallinn: Eesti Keele Sihtasutus, 2007). 431-432, 445,688 ). Järgnes aga vaikus, raamatuid ei avaldatud, pagulased jäeti kirjandusloost ja luuleantoloogiatest välja ning nende kohta ilmuvate kirjutiste sõnavara ja hinnanguid valvati hoolega.

59 Vt ülevaatlikult nt Kuuli, Sula ja hallad Eesti NSV-s, 45-53, 74-81.

60 Eesti kirjanduse ajalugu 4: õpik keskkooli XI klassile, toim Endel Sõgel (Tallinn, 1953).

${ }_{61}$ Eesti kirjanduse ajalugu 3, toim Endel Sõgel (Tallinn, 1956).

62 Ahven, Pilk paberpeeglisse, 194.

63 Heino Puhvel, "Kultuurielu ja kirjanduse arengujooni aastail 1907-1917", Eesti kirjanduse ajalugu III (Tallinn, 1969), 318-321. 
Oluline teema oligi debatt mõistete üle. Väga üldiselt võib öelda, et kunsti nähti kümnendi esimesel poolel endiselt ühiskonnast sõltuvana, aga terav kultuuri klassiiseloomu, parteilisuse ja kahe kultuuri rõhutamine jäi vaid stalinistide pärisosaks. Konkreetsemalt toodi 1960. aastate keskpaigas ja teisel poolel kirjanduskirjutusse tagasi eesti sõjaeelne modernsete voolude terminoloogia. Stalini aeg oli võtnud kasutusele nõukogude vene mõistestiku, milles keskset rolli mängisid dekadents ja formalism (mida iseloomustasid mh loomalikud instinktid, künism, valelikkus jne). Selle aja vaated peegelduvad hästi Bernard Söödi "Kirjandusteooria lühikursuses" (1959). ${ }^{64}$ 1950. aastate lõpust hakkasid sõjaeelsed uusromantika põhimõisted vaikselt esinema positiivsete konnotatsioonidega. Esmalt (1962) toodi tagasi kõige süütum nähtus impressionism. ${ }^{65}$ Pööre saabus 1966, kui ilmus "Kirjandusteooria lühikursuse" uusväljaanne, milles autor oli oma hinnanguid pehmendanud, kuid jäänud sisuliselt samadele positsioonidele. ${ }^{66}$ Nüüd tõi see avaliku vaidluse, milles Söödile astusid vastu Ants Järv, Ain Kaalep ja Nigol Andresen. ${ }^{67}$ Samadel aastatel (1966-68) toimus ka ekspressionismi avalik rehabiliteerimine, milles mängis keskset rolli N. Andresen, tema kõrval Harald Peep. ${ }^{68}$ Vastupanijad kasutasid sealjuures tolles ajas tavalisi võtteid, tõstes kaitstavates nähtustes esile jooni, mida sai haakida nõukogude ideoloogia serva (humanism, sõjavastasus, side reaalsusega, idealistliku ideoloogia puudumine), lahutasid vormivõtted filosoofiast/ideoloogiast ning hajutasid mõistete piirid ebamääraseks (nt autor ei ole mitte sümbolist, vaid sümbolismimõjuline).

\footnotetext{
64 Bernard Sööt, Kirjandusteooria lühikursus (Tallinn: Eesti Riiklik Kirjastus, 1959).

65 Heino Puhvel, "Impressionismist ja selle mõjust eesti kirjandusele XX sajandi alguskümnendeil”, Keel ja Kirjandus, 6-7, (1962), 329-340, 393-404.

66 Bernard Sööt, Kirjandusteooria lühikursus (Tallinn: Valgus, 1966).

67 Vt nt Ant Järv, "Kirjandusteooria lühikursusest ja kirjanduslikust mõttest”, Edasi, 22.05.1966; Ain Kaalep, "Muretsemisi värske kirjandusteooria käsiraamatu puhul", Sirp ja Vasar, 10.06.1966; Nigol Andresen, "Mineviku vooludest ja nende ratsionaalsest tuumast", Sirp ja Vasar, 05.08.1966; Bernard Sööt, "Vastumuretsemisi "Kirjandusteooria lühikursuse" kriitika puhul”, Sirp ja Vasar, 29.07.1966; Bernard Sööt, "Veel vooludest ja kirjanduse hindamisest", Sirp ja Vasar, 19.08.1966. Huvitavat taustainfot leiab kirjavahetusest: "Kaks vaimukaaslast eri aegadest: valik Ain Kaalepi ja Nigol Andreseni kirjavahetusest aastatel 1965-1975", Tuna, 4 (2007), 116.

68 Nigol Andresen, "Kirjandusliku ekspressionismi mõnest joonest", Keel ja Kirjandus, 9-10 (1966), 521-528, 593-6o1; "Uue kirjandusliku epohhi algusest Eestis (I)", Keel ja Kirjandus, 9-10 (1968), 513-522, 597-602; Harald Peep, "Ajaluule poeetikast, ajast ja luulest”, Harald Peep, Pilk peegli taha (Tallinn, 1967), 134-159.
} 


\section{0.-80. aastate vastupanu}

1968. aasta ja vägede tungimine Prahasse said Nõukogude Liidu elus pöördepunktiks. Algas ajajärk, mil kogu riigis hakati kruvisid üha tugevamini kinni keerama. Marksistlik-leninlik ideoloogia kui ühiskonna alus püsis, kuigi muutus kohati pigem tühjade fraaside kogumiks. Uue suunana algas 1970. aastate keskpaigast venestamine. Juba 1961 oli N. Hruštšov leidnud, et on välja kujunenud uus ajalooline paljurahvuseline nõukogude rahvas, 1977. aasta uues Nõukogude Liidu konstitutsioonis fikseeriti see mõiste ka ametlikult ("uus ajalooline inimühendus - nõukogude rahvas"). Sellega koos algas 1970. aastate keskpaigast mittevene rahvuste ja keelte allasurumine, kaugema eesmärgina nende täielik hävitamine.

Teisalt saame kõnelda ka inimeste mugandumisest. 1970. aastatel kujunes Eestis välja sotsialistlik tarbimisühiskond, inimeste ideaaliks sai auto, suvila, oma maja omamine. 1960. aastatel haritlastele siiski oluline "inimnäoga sotsialismi" otsiv ideoloogiline vasakpoolus asendus kohati avaliku, kohati varjatud karjääriparteilisusega (mh astusid parteisse mitmed senised vastalised kirjanikud). Kujunes välja avalik kaksikmoraal. Intelligentide seas asendus avatus ja optimism enesesse pöördumise ja skepsisega progressiusu suhtes.

1968.-69. aastaks olid eesti kirjanduses olulised esteetilised võitlused võideldud. Mitteideoloogiline kirjandus ja avangard-modernism olid aktsepteeritud, sotsialistlik realism sisuliselt lõppenud, keelatud estetistlikud mõisted kasutusel, mittemarksislik mõtlemine kirjanduses sisuliselt lubatud. ${ }^{69}$ Aegajalt jätkasid partei ja tsensuur endiselt esteetilist võitlust, kuid piiranguid see kirjanduses kaasa ei toonud. ${ }^{70}$ Samas tugevnes kultuuris üha enam ideoloogiline tsensuur, eriti kirjanduses, mida sai tehniliselt kergesti mõjutada.

Sel perioodil saab taas enam kõnelda ka kirjanduse suunamisest partei dokumentide abil. Oluliseks tähiseks on siin 1972. aastal ilmunud NLKP Keskomitee otsus "Kirjandus- ja kunstikriitikast". Aegade muutumist eesti kirjanduses näitab aga asjaolu, et tõlke asemel esitab ajakiri Looming vaid referaadi ning Paul Kuusberg oma teemakohases artiklis toonitab, et inimestes endiselt püsiv hirm taasalgava stalinistliku "kampaania" ees on

\footnotetext{
69 Kajar Pruul on proovinud leida sotsialistliku realismi jooni 1980. aastate Loomingus ilmunud luules, kuid isegi mõiste ümberdefineerimine lõdvemaks annab tulemuseks vaid kilde ning ka funktsionääride kõnedes see sõna vaid vilksatab. Vt Kajar Pruul, "Sotsialistliku realismi lõpp", Looming, 4 (1998), 626-635.

70 Eesti kirjandus oli siin suuresti erand, nt vene kirjanduses oli suhtumine avangardismi-modernismi endiselt negatiivne. Samuti olid käsud-keelud teravamad kujutavas kunstis.
} 
asjatu. ${ }^{71}$ Kuusberg vaatab oma artiklis üle suurema osa eelneva perioodi olulistest võitlustest, rõhutades pidevalt vajadust arutada ja mitte pead liiva all peita, marksistlikult hinnata ja mitte vulgaarselt kärkida. Kriitikalt oodatakse ikka eeskätt ideeliste hinnangute täpsust, alles selle kõrval ka sotsiaalset analüüsi ja esteetilist nõudlikkust. Aegade muutumise ilusaks pisimärgiks on lõik, milles Kuusberg toob esile vajaduse näidata marksistlikust esteetikast eemalduvate käsitluse ühekülgsust kirjanduses, aga kasutab modernismi vastu tsitaati tõepoolest üldiselt modernismivaenulikult pagulaskriitikult Ants Oraselt.

Uues olukorras muutus vastupanu kese ja esile tõusis rahvuslik vastupanu, nii rahvuse ühendamine kui ka vastupanu venestamisele. Samuti muutusid vastupanu vormid, keskseks tõusid salakoodid ja võitlus sõnade-mõistete eest.

\section{Rahvuslus, vabadus ja salakoodid}

1970.-80. aastatel sai keskseks varjatud vastupanu, mis kasutas kirjaniku ja lugeja ühiseid salakoode. See on totalitaarses või autoritaarses ühiskonnas laialt levinud vastupanuviis, mille puhul iga kujund, motiiv või süžee võis osutuda režiimi poolt tabustatud nähtuse metafooriks. Siia kuuluvad topeltkoodid, märksõnad, vihjed, iroonia, paroodiad jms. See vastupanu oli loomulikult olemas ka 1960. aastatel, kuid tõusis esile just 1970. aastatel koos ideoloogilise tsensuuri karmistumisega. Vihjeid otsisid nii lugejad kui tsensor, nende otsimine muutus omaette lugemistrateegiaks.

Kõige enam on salakoodivastupanust rääkides toodud esile nähtust, mida Kajar Pruul on nimetanud etnosümbolismiks. ${ }^{72}$ Siin võeti kasutusele tabustatud etniliste sümbolite või rahvusliku ajaloomüüdi metafoorid või kirjanduslikud trikid, koodi käivitajaks sai kollektiivi ajaloomälu ja eesmärgiks rahvusliku samastumise saavutamine. Selliseid salakoode oli täis Hando Runneli luule, aga ka nt üldiselt vähepoliitiline Jüri Üdi. Olgu näiteks tema "Lihtne luuletus" (1971), milles fraasitunud laulureast "õnn tuli õuele" arendatakse pilt, milles õnn täidab kõik vana talu hooned, kuni "rõivad veel mahtusid kohvrisse / siis pidi minema". Vihje taluelu hävitamisele ja küüditamisele ei ole just raskesti välja loetav. ${ }^{73}$ Ilmselt kuulsaimaks

\footnotetext{
71 “NLKP Keskkomitees: kirjandus- ja kunstikriitikast", Looming, 2 (1972), 179-181. Vrd: Literaturnoe dvizhenie Sovetskoù épokhi: materialy i dokumentȳ (Moskva: Prosveshchenie, 1986), 255-258; Paul Kuusberg, "Mõningaid kriitikamõtteid”, Looming, 6 (1972), 1018-1030. 72 Kajar Pruul, "Etnosümbolism ja etnofuturism: teese revolutsiooniaegsest kirjandusest”, Vikerkaar, 12 (1995), 58.

73 Jüri Üdi, Detsember (Tallinn: Eesti Raamat 1971), 9. "Õnn tuli meie õuele, / au kolhoosi korrale." Juhan Smuuli laulutekstist mängufilmile "Valgus Koordis" (helilooja Boris Kõrver).
} 
kirjandusliku triki näiteks sai kunstitudeng Andrus Rõugu akrostihhon, mille värsside esitähed annavad ülalt alla kokku lugedes "sinimustvalge", mis oli üks tabulisemaid sõnu üldse. ${ }^{74}$

Selle kõrval oli oluline püsiv võimalus kirjutada sellest, mis ei olnud otseselt keelatud, kuid samas mitte ametlikult soositud. Siia kuulub sel perioodil nt külakirjanduse tõus (Hando Runnel, Mats Traadi romaanid, nt "Tants aurukatla ümber" (1971) jt), ajalooproosa, mis mütologiseeris eestlaste ülipikka ajalugu ning arutles vastupanu ja kompromisside üle (Lennart Meri, Jaan Kross jt) ning sõjaromaanid, mis ei kirjutanud Suure Isamaasõja heroilisest võitlusest, vaid kujutasid sõda tavalise sõduri perspektiivist (nt Juhan Peegli "Ma langesin esimesel sõjasuvel" (1979)). ${ }^{75}$ Need tekstid kasutasid sealjuures ära ka salakoode ja vaikimisi. Selle kõrval proovisid samad autorid tihti piire ületada ja mõnikord see ka õnnestus (kuulsaim näide on Hando Runneli luulekogu "Punaste õhtute purpur" (1982)). Nii võime öelda, et see kirjandus oli kindlasti osa võitlusest rahvusühtsuse ja rahvuse säilitamise nimel.

Salakoodide kasutuse teise suuna moodustasid märgid, mis viitavad vabale maailmale, kuhu tavalisel nõukogude Eesti inimesel pääsu ei olnud. Mihkel Muti jutustuses "Võta end koomale, elu!" (1980) läheb peategelane Tallinna kesklinnas asuvasse baari kohvi jooma ja leiab, et seinalt on "lõpuks koristatud loosung "Merry Christmas!"”. ${ }^{76}$ Selline loosung viitas maailmale, kus oli normaalne vabadus jõule pidada ja seda avalikus ruumis manifesteerida. Samasse sarja kuuluvad sümbolid ja märgid, mis viitasid Soomele, Rootsile, Ameerikale, Hollywoodile jms. Johanna Ross on tõlgendanud Katrin Kivimaale toetudes nt Hollywoodi filmidiivadele viitavaid märksõnu kui assotsiatiivseid viiteid vabariigile ja kaotatud rahvusriigi metonüüme. ${ }^{77}$ Kindlasti oli see ideoloogiline sõnakasutus ja võis ehk meenutada assotsiatiivselt ka vabariigi aega. Minu tõlgenduses on need siiski märgid vabast maailmast ning see vastupanu seostub ennekõike vabadusega.

Salakoodide kui vastupanuvõtte eemärgiks oli äratada märgi kaudu üles lugeja mälu ning eeldada, et see konstrueerib ise vajaliku narratiivi.

\footnotetext{
74 Andrus Rõuk, “Silmades taevas ja meri”, Looming, 9 (1981), 1311. Vrd Arvi Siia akrostihhon ideoloogilisest vabadusest, luuletuse teemaks on nööri otsas käivad mudilased ja esitähed annavad kokku fraasi "kogu tõde". Arvi Siig, "Lasteaiatädi", Sirp ja Vasar, 10.03.1967.

75 Tegemist ei ole eesti kirjanduse eripäraga. Samasugune "kaevikusõja"-käsitlus ja rahvuslik külahävimise-vastane kirjandus tõusis ka Venemaal, vt Istoriya russkǒ̆ literatury XX veka, ch. 2, 393-406.

76 Mihkel Mutt, "Võta end koomale, elu!", Mihkel Mutt, Fabiani õpilane (Tallinn: Eesti Raamat 1980), 73.

77 Ross, Aira Kaalust Mari Saadini, 127.
} 
Nagu nägime, võis olla tegu nii rahvusliku ühendamise kui vabadusele viitamisega. Igal juhul oli tegu ideoloogilise vastupanuga. Sealjuures on siin oluline välja tuua üks paradoks. Nimelt olid raamatute tiraažid tol perioodil hiigelsuured (realistlik romaan 40000 , modernistlikum romaan u 20 000) ja nimetusi vähe. Seda poliitikat on nõukogude aja järel palju hukka mõistetud. Samas tagasid just suured tiraažid ja ühiste raamatute lugemine kirjandusele rahvuse sidustaja rolli ja aitasid kaasa kirjanduse vastupanurollile. Vastupidine (väikesed tiraažid ja palju nimetusi) oleks tegelikult lahutanud ühiskonna gruppideks ja teinud ühistele koodidele mängimise raskeks.

\section{Vaikimine kui vihjamine}

Salakoodide kõrval oli oluline vihjamine vaikimisega, nii kirjanduses (ennekõike luules) kui kriitikas.

Ennekõike 1970. aastatel kujunes välja Stalini ajast erinev tekstisisene vaikimine, nn pauside luule. Selle taga oli ühelt poolt tüdimus 1960. aastate vohavast paljusõnalisest luulest, teiselt poolt aga sai sellest ka vastupanuvõte, mis toetus ideoloogiavaba teksti võimalusele, andes samas lugejale võimaluse täita pausid vastupanule sobiva sisuga. ${ }^{78}$ Vaikimise luule keskne esindaja oli Jüri Üdi (Juhan Viiding), kelle luuletamisviis leidis omas ajas palju järgimist. ${ }^{79}$

Stalini ajal oli kriitika põhimõtteliselt võimu esindaja, kes tõi päevavalgele kirjanikust "rahvavaenlase" tegevusi. Stalini järgsel perioodil asetus osa kriitikast kirjanikuga samale poolele. Kujunes välja nö vastupanukriitika, millel on kaks tahku: vaikida negatiivsetest hinnangutest, mis võinuks anda alust autori poliitiliseks süüdistuseks ning vaikida seikadest ja salakoodidest, mida võim ei pidanud teadma. Vastupanukriitika sai alguse 1960. aastatel, aga tõusis olulisemaks just suletud 1970.-80. aastatel. Mihkel Mutt on kirjutanud sellest, kuidas Jaak Allik teda noomis 1980. aastate alguses teatriarvustuse eest (kasutades sõna donos'- vn k pealekaebus). ${ }^{80}$ Tema sõnum oli selge. Aus kriitik peaks teost kiitma nii, et lugeja saaks ridadevahelisest sõnumist aru, aga võim mitte. Seni, kuni keegi pole teose või

\footnotetext{
${ }_{78}$ Siinkirjutaja vaateid laiemalt sellele perioodile vt Tiit Hennoste, "Hüpped modernismi poole: eesti 20. sajandi kirjandusest Euroopa modernismi taustal, 20. loeng: lagunemine I", Vikerkaar, 5-6 (1996), 142-149; Ibid., 21. loeng: kodueesti modernism 4: lagunemine II", Vikerkaar, 1-2 (1997), 115-127.

79 Külliki Vulf, "Vaikimine - vabastav võimalus kõnelemiseks: kas võimalus kohandumiseks?", Kohandumise märgid, 284-30o.

80 Mihkel Mutt, Mälestused VI: elukott (Tallinn: Fabian, 2011), 122-123.
} 
lavastuse vastalisust otsesõnu välja toonud, on see sageli ka lubatud. Pärast seda on aga ka asjasse positiivsemalt või vähemalt neutraalselt suhtuval võimuesindajal raske näiteks teatrilavastust mitte ära keelata.

\section{Võitlus mitteideloogiliste sõnade eest}

Jätkuv teema oli võitlus mitteideoloogiliste konnotatsioonidega sõnademõistete eest nõukogude võimule ideoloogiliselt oluliste nähtuste tasandil (Eesti Vabariik, sinimustvalge, isamaa, 1940. aasta Eestis, Suur Isamaasõda, metsavendlus, pagulased, küüditamine, kollektiviseerimine, jõulud jms).

Siin oli tegemist kolme liiki keelekasutusega, mille illustreerimiseks sobivad näited Sirje Kiini päevikust aastal 1980 (Kiin oli ajakirja Keele ja Kirjandus asetoimetaja). ${ }^{81}$ Üks variant oli võitlus ideoloogiliste konnotatsioonidega mõistete ümber, milles tavaliselt areeniks ideoloogiline kolmikjaotus: ühele poole jäi ametlikku doktriini väljendav mõiste, teisele poole täiesti keelatud mõiste ja keskele väljavõideldav territoorium, mis kasutas neutraalset üldsõna-eufemismi. Kiin kõneleb nt nõudest asendada neutraalsed "1940. a juunipööre" ja "1940. a sündmused" ideoloogiliselt laetud sõnaga "revolutsioon". Teine variant oli võitlus täiendite eest (nt käsk lisada neutraalsele "Saksa okupatsioonile" juurde täiend "fašistlik"). Kolmas võitlus piirnes eelmisega ja seisnes hinnangute doseerimises, nt käsk võtta pagulaskirjanik August Mälgu juubeliartiklist maha positiivseid hinnanguid.

Oluline muutus toimus huumoris ja satiiris. Uut perioodi iseloomustavad keele- ja absurdinaljad, paroodiad ning ridadevaheline nõukogudevastasus. Üheks aknaks sai siin Toomas Kalli poolt 1971. aastal välja kujundatud ja toimetatud Sirbi ja Vasara viimane, kuueteistkümnes lehekülg, selle kõrval Tartu ajalehe Edasi iganädalane huumorikülg, aga muutus ka Pikker. Oluliseks vastupanuvahendiks sai veste, mille tegelased osutasid "ühiskonna väärnähtusetele" nii, et osutusid ise läbinähtaval moel nõukogude korra paroodiaks. Selliste tegelaste kuulsaim esindaja oli Harri Lehiste loodud kodanik Tsäbovõitra (1975-76). See oli valvas inimene, kes kaebas kõigi (ja eriti kodanik Tofelmanni) peale nõukogudevastase tegevuse pärast, kasutades keelt, milles oli ühendatud sovetlik/stalinistlik sõnavara ja grammatiliselt vigane lause ("Nüüd on kodanik Tofelmann saanud hakkama ennekuulmatu diversiooniga ja langenud ja keegi ei võta tarvitusele."). ${ }^{82}$

81 Sirje Kiin, Pühendused: mälestusi eesti kirjanikest (Tallinn: Hea Lugu, 2018), 102-103.

82 Harri Lehiste, Valitud kaebused: vested ja humoreskid (Tallinn: Eesti Raamat, 1990), 201. 


\section{Kokkuvõte ja arutlus}

Kirjandusloo üldpilt kasutab nõukogude aja kirjanduse puhul tugevalt rahvuslik-vastupanulist lugemisviisi, mis näitab kirjandust kui võitlust eesti rahvuse ja nõukogude võimu, eesti kirjanduse ja nõukogude kirjanduse vahel, milles "salakoodid" ühendasid kultuuritegijaid ja rahvast. Minu arusaamade järgi ei ole selline redutseerimine viljakas, sest jätab kõrvale nähtusi, mida saaks käsitleda vastupanu võtmes ning teisalt interpreteerib kogu vastupanu ühes võtmes.

Käesolevas proovisin esile tuua, et vastupanu jagunes erinevateks variantideks oma eesmärkide poolest: ideoloogiline vastupanu nõukogude võimule, rahvuslik vastupanu, esteetiline vastupanu ja vastupanu üldise või isikliku vabaduse ehk autentsuse nimel, mis võivad muidugi põimuda. Teiseks tõin välja erinevad vastupanu viisid: vaikimine tekstide tasandil kas täielikult (nn sahtlisse kirjutamine) või osaliselt, tekstisisene vaikimine sõnade/fraaside tasandil, "salakoodide" kasutus, omakirjastamine, võimu poolt mittesoositud ja mittepoliitiliste/-ideoloogiliste teemade või kirjutusviiside valimine, võitlus neutraalsete, mitteideologiseeritud või mittenõukogulike sõnade, mõistete, kirjutusviiside, käsitlusviiside eest.

Proovisin näidata, kuidas Eesti NSV ajaloo eri perioodidel olid kirjanduses fookuses erinevad vastupanu variandid ja vastupanuviisid.

Stalini aja vastupanu põhivorm oli vaikimine, nn sahtlisse kirjutamine. Vähemalt osa vaikimisest, ennekõike luule puhul võib tõlgendada vastupanuna esteetilise autentsuse nimel, mitte niivõrd ideoloogilise või rahvusliku vastupanuna.

Sulaperioodil muutus kirjanduslik vastupanu radikaalselt. Sisuliselt lõppes vaikimise ja sahtlikirjanduse aeg, kirjanikud mugandusid süsteemiga piisaval määral, et liikuda vajadusel lubatu ja lubamatu piiril. Algas ajajärk, mille keskmes oli avalik vastupanu, mis väljendus mh erinevate debattides, selle kõrval toimus muidugi ka varjatud vastupanu.

Läbi kogu perioodi oli oluline esteetiline vastupanu, mis haaras kõiki ždanovliku kirjandusdoktriini elemente ja lõppes 1968.-69. aastaks. Mitteideoloogiline kirjandus oli aktsepteeritud, sotsialistlik realism sisuliselt lõppenud, avangard-modernism alanud ja aktsepteeritud, mittemarksislik mõtlemine kirjanduses kaudselt aktsepteeritud.

Teiseks käis läbi kümnendi vastupanu rahvusühtsuse ja rahvusliku mälu nimel. See oli vastupanu kirjandusloo tagasitoomise ja sõjaeelse metakeele kasutamise nimel ning ka paguluse ja kodueesti ühendamise nimel. See võitlus oli üldiselt edukas, vaid pagulaste ühendamine jäi 1960. aastate keskel hetkeks, mis hiljem enam ei kordunud. Kolmas võitlus käis 
loominguvabaduse ja sisemise autentsuse nimel. Selle võitluse alguseks oli võitlus esteetilise vabaduse ja autentsuse nimel, lõppu jäi võitlus üldise sisemise autentsuse nimel.

Tolle perioodi vastupanu murdehetk koondub aastatesse 1965-67. Samas ei saa öelda, et see oleks kuidagi kavandatud murdehetk, sel ajal lihtsalt saavad kokku mitmed edukad võitlused. Ka ei ole siin seoseid Hruštšovi aja lõppemisega aastal 1964.

1970. aastate alguses algas vastupanu kolmas periood, mis tõstis esile uued teemad ja vastupanuvõtted. Osalt olid need tingitud "kruvide kinnikeeramisest" ühiskonnas, teisalt oli muutumine on seotud ka sellega, et esteetiline vabadus oli tolleks ajaks saavutatud.

Selle perioodi vastupanu keskmes oli rahvuslik vastupanu, rahvuse ühendamine, kusjuures uue aspektina tõusis esile vastupanu venestamisele. Avalik võitlus taandus tagaplaanile, keskseks sai salakoodide kasutus. Ühtlasi toimus nüüd võitlus ennekõike üksiktestide sees, märksõnade, vihjete, tekstisiseste vaikimiste kaudu, kasutades ära tolleks ajaks kättevõideldud esteetilisi vabadusi. Selle kõrval jätkus võitlus metakeele, sõnade, mõistete nimel, eesmärgiks saavutada maksimaalne võimalik neutraalsus.

Üldine põhimõte jäi: jätkata vastupanu ka siis, kui see tundub absurdne ja lootusetu, et mitte langeda müüriga ümbritsetud suletud ruumi ohvriks.

\section{ABSTRACT: Literature as resistance in Soviet Estonia in the post- World War II period}

The theme of this article is the resistance that took place in Soviet Estonian literature, literary criticism and literary studies in the post-Second World War period. The article accentuates that different modes and objectives of resistance were central in different periods.

Literary resistance is divided into four groups according to the nature of the pressure and the aims of resistance: first, ideological resistance to Soviet ideology in the name of literature that is free of ideology, or in the name of some other ideology; second, national resistance in the name of the unity of the people and preservation of identity; third, aesthetic resistance to the official literary doctrine; and fourth, resistance in the name of general or personal freedom and authenticity. 
Writers and literary scholars used different modes of resistance. These were so-called writing for the desk drawer, silence within a text, the use of 'secret codes', self-publication, the selection of themes or modes of writing that were not favoured by the regime and were apolitical and nonideological, and the use of neutral words and concepts instead of concepts and words bearing Soviet ideology.

Totalitarian control of literature by way of decisions and direct instructions from the Communist Party characterised the Stalinist period (until 1956). All literature had to adhere to the doctrine of socialist realism. Practically the only form of resistance in this period was to keep silent. Some authors remained completely silent, some worked on translations, some wrote for their desk drawer for themselves and presented texts for publication that adhered to the officially sanctioned model. Keeping silent can also be interpreted as resistance in the name of aesthetic authenticity.

The subsequent period that lasted until the 1970 s is characterised by an increase in liberty in society, including literature. The body of norms of socialist realism was relaxed. Literary activities were controlled by writers' organisations according to the guidelines provided by the Communist Party. Different aesthetic and ideological camps of writers emerged and competed with one another. The era of keeping silent and writing for one's desk drawer ended. Public resistance, which was united by the question of relating to literature that preceded the Soviet era, was at the centre of this period. The fight for aesthetic freedom and literature that was free of ideology carried on throughout this period and was finally won by 1968-69. By that time, socialist realism had essentially ended in Estonian literature. In place of it, avant-gardism, modernism and broader realism prevailed. In place of Marxism-Leninism, non-Marxist ways of thinking had become important: first and foremost existentialism, but also Buddhism, Zen Buddhism, Taoism and classical psychoanalysis.

Secondly, resistance was put up in the name of Estonian national unity and national memory. This was resistance in the name of authors who had been banished from the history of literature and of bringing back the prewar metalanguage. This was concerned with modern writers (symbolists, decadents, impressionists, expressionists) in Estonian literature from the early 20 th century. Generally speaking, this struggle was successful.

The third struggle was waged in the name of creative freedom and the writer's inner authenticity. Here political freedom and independence in general intertwined as ideals, with the Soviet system and any kind of system as the enemy that oppresses human freedom and independence: 
institutions and the state, machines and rationality, conformism and the middle class way of life.

The third period of resistance began at the start of the 1970 and continued until perestroika. The so-called tightening of the screws took place throughout the state during this period and Russification was adopted as a new orientation starting in the mid-1970s. On the other hand, a socialist consumer society took shape in Estonia, characterised by Communist Party membership for the sake of one's career and openly double morality. Ideological censorship in literature was intensified, along with the partial steering of literature by way of Party documents. Such new conditions brought new variants of resistance to the fore.

Nationalist resistance and resistance to Russification came to the fore in the 1970 and 1980 os. Open struggle receded into the background. Covert resistance, primarily within individual texts, which had previously been insignificant, became central. This resistance used joint secret codes common to writers and readers (allusions, irony, parodies, and other such devices). The struggle continued in the name of a neutral metalanguage that is not ideologised. Resistance criticism, so to speak, took shape: keeping silent about negative assessments that could potentially have provided the basis for political accusations, and keeping silent about secret codes in texts that the authorities did not have to know about.

The struggle for words and concepts without ideological connotations at the level of phenomena that were ideologically important for the Soviet regime was a continuing theme: the Republic of Estonia, the blue, black and white colour combination, expatriates, deportation, and other such concepts.

KEYWORDS: Estonian literature, Soviet Estonia, freedom, ideological resistance, aesthetic resistance, national resistance, modes of resistance.

Tirt Hennoste (b. 1953) is a Senior Researcher at the Institute of Estonian and General Linguistics, University of Tartu.*

* Correspondence: Institute of Estonian and General Linguistics, University of Tartu, Jakobi 2, 51014 Tartu, Estonia. E-mail: tiit.hennoste@ut.ee 